\title{
Importance and challenges of women entrepreneurship - A case study of Sonitpur district of Assam
}

\author{
Mala Mahanta, \\ Deptt. Of EconomicsL.G.B.Girls' College, TezpurSonitpur, Assam -784154
}

\begin{abstract}
Entrepreneurship is a major strategy for economic development of a country. An entrepreneur is an important constituent of the development process and an integral part of the socio-economic transformation process. As such entrepreneurship is a purposeful pursuit towards initiating, promoting, innovating and mainstreaming economic activities for production and distribution of wealth. Development of a society requires full participation of all section of population including women. Entrepreneurship development among women can be considered a possible approach to economic empowerment of women. A women entrepreneur is economically more powerful than as a mere worker because ownership not only confers controls over assets but also give her the freedom to take decision. This will uplift her social status significantly. Though Indian women are playing important role in society, but their entrepreneurial activities are yet to be explored. Government (at central and state) has undertaken various policies during the fiveyear plan periods for the development of women entrepreneurship. Consequently, there has been considerable development of women entrepreneurship in Assam. But the field of women entrepreneurship in Assam is full of problems. This paper has given emphasis on prospects and challenges of women entrepreneurship in Tezpur town of Sonitpur district of Assam. The population of the study consists of registered and unregistered women entrepreneurs. A sample of 50 women entrepreneurs are selected for the study on the basis of random sampling. This paper has to explore the hidden prospects of women entrepreneurship and also forwarded some suggestions in improvement of women entrepreneurship in Tezpur.
\end{abstract}

Key words: Entrepreneurship, challenges, empowerment, transformation, pursuit.

\section{INTRODUCTION}

Entrepreneurship is a creative process in which specific goals are achieved using various resources in a planned and coordinated manner to perform activities in efficient way. The term 'entrepreneur' is of a relatively recent origin and evolving one also. It is mainly associated with economic and industrial development of an economy. Richard Cantillon, an Irishman living in France, was the first who introduced the term 'entrepreneur' and his unique risk-bearing function in economics in the early $18^{\text {th }}$ century. He defined 'entrepreneur as an agent who buys factors of production at certain prices in order to combine them into a product with a view to selling it at uncertain prices in future'. Women entrepreneurship has been recognised as an important source of economic growth. Entrepreneurship happens to be one of the best way towards self-sufficiency and poverty alleviation for women in a country where employment is not guaranteed. Involvement of women in entrepreneurial activities would ensure effective utilization of labour, generation of income and hence improvement in standard of living. Initially, women have been confined to the private sphere of the household doing the daily works and tending to her family's needs. Therefore they have been denied access to the requisite resources for entrepreneurial entry access to capital, business and technical education, and prior management experience Though Indian women have played a key role in the society, their entrepreneurial quality has not been properly utilized due to lower status of women in society. Since $5^{\text {th }}$ Five Year Plan onwards women's role has been recognized with a marked shift in the approach from women welfare to women development and empowerment. Several policies and programmes are being implemented for the development of women entrepreneurship. Consequently, women participation in business has shown considerable improvement in India and Assam. The modern concept of women entrepreneurship took shape in North Eastern region of the country on from the eighty. Contrary to the popular notion that women from the NE region are still backward, they have come a long way now and have established themselves as successful and thriving entrepreneurs not only in the region but also beyond the boundaries of the India. Like most women entrepreneurs in India, the women from North East region have also embarked on their entrepreneurial journey in a relatively smaller scale, mostly based out of their homes. They began with traditionally women-oriented business like garments, fashion, handloom and handicraft, beauty and well-being, etc. mostly without any formal training or a rigid business frame work. Women from the region have realized the potential resources of the region and have initiated various entrepreneurial activities in order to tap the natural wealth of the nation. The name Lalita Devi Jain, fondly known as Madhu by the people of 
Guwahati, Assam has shaped her own destiny in the entrepreneurial arena. She created her own brand "Madhushree" and has marched her way forward to carve a niche in the global market. She started with five looms and over the period of last more than 25 years, she has built up 50 looms. Almost 200 women are employed and they all have become the part of the family to create the brand of Madhushree.

\section{AREA OF THE STUDY}

The area of the study is Sonitpur district of Assam. Sonitpur district is purposely selected as this district has the potential to probe into the entrepreneurial behaviour among the women. Literacy rate among the women in Sonitpur is 60.73 percent (according to 2011 census).

It is an agricultural based district. Traditional dependence on agriculture is one of the reasons for lack of entrepreneurship among the educated youths. They are mostly concentrated on governmental jobs. Absence of major industries in Sonitpur is also partly responsible for lack of entrepreneurial activities. In Sonitpur district number of registered Industrial unit is 2910. Out of this number of women entrpreneurs are only 255. Sonitpur is an administrative district in the state of Assam. The district headquarter is located at Tezpur. As of 2011, it is the third most populous district of Assam (out of 27), after Nagaon and Dhubri. Sonitpur district was created in 1983 when it was split from Darrang district. It is the fifth largest city of Assam after Guwahati, Jorhat, Dibrugarh and Silchar. Sonitpur district occupies an area of 5,324 square kms (2,056 square ml.). According to 2011 census, total population of Sonitpur district is 1,924,110. Sex ratio, density of population, female literacy and male literacy rate are 956 per 1000 male, 370 per square km, 60.74 percent and 73.65 percent respectively. Sonitpur is home town of two wildlife sanctuaries- Burachapori and Sonai-Rupai. In 1998 Sonitpur district became home to Nameri National Park which has an area of $200 \mathrm{~km}$. It is also home to Orang Natonal Park, which it shares with Darrang district. It was established in 1999 and has an area of $79 \mathrm{~km}$.

Sonitpur is a land of natural beauty, ancient monuments and rich cultural heritage. Tezpur is an important tourist destination with beautiful parks, temples and ancient monuments. Tourist spots in Tezpur town are mainly Chitralekha Udhyan, Agnigarh, Mahabhairab temple, Bhairabi temple, Rudrapada Temple, Haleswar, Da Parbatia, Hazara Pukhuri, Bamuni Hill, and Bhomoraguri.

\section{Objectives:}

1. To study the necessity of women entrepreneurship in Sonitpur district

2. To find out the challenges of women entrepreneurs in Sonitpur.

3. To study the ways of overcoming the barriers of women entrepreneurship.

\section{REVIEW OF LITERATURE}

\section{Review in international perspective}

In 1987, Van der and Ronji in a study on small enterprises run by women observed that business headed by women were consistently worse off than others. The few factors responsible for this were, they generally had fewer resources than men, lower level of education and literacy, and by restricted physical and occupational mobility.

Global Entrepreneurship Monitor (GEM) researchers in 1999 found that the level of entrepreneurial activity among women increases as level of education rise, with a major jump in business ownership seen among those who go beyond a secondary education. This pattern is different from that of men. The highest levels of business activity among men are seen among those who have only a secondary education; the lowest levels of entrepreneurship are seen among those man who have both the most and the least amount of education. According to GEM reports, to increase the level of entrepreneurial start-up efforts by helping to get more women involved and highlighting successful women entrepreneurs who could serve as role models and encourage other women to start their own business.

Moore (1992) observed, relative to corporations, that strategy formulation is not the singular product of one person's mind, but a continuing organizational activity. The validity of this perspective requires further exploration within the domain of the entrepreneurial firm. In this context, for a small to medium-sized enterprise, the one person very often equates to the total organization, or may at least dominate its decision making.

According to a 1995 report by the United Nations Industrial Development Organization (UNIDO), "despite evidence that, women's loan repayment rates are higher than men's, women still face more difficulties in obtaining credit," often due to discriminatory attitudes of banks and informal lending groups.

Amha \& Ademassie(2004), their study say that more than half of all women entrepreneur in Ethopia face gender related challenges to establish operating and expanding their entrepreneurial activities. 


\section{REVIEW OF LITERATURE IN NATIONAL PERSPECTIVE}

In 2004, Papisetty Rama Mohan Rao found in the research study that inadequate infrastructure, high labour mobility, shortage of electricity and delayed realization of debtors were the main problems faced by women entrepreneurs.

In India, the complicated relationship between the domestic responsibilities of women and their great potential to be successful entrepreneur has been noted in a number of industries such as knitwear and garments (Vijayabhaskar, 2002; Sing and Sapra, 2007). These jobs provide limited opportunity for upward mobility (Neetha, 2002). Various socio-cultural and political factors are responsible for such gender biases, which are gradually being overcome but not properly, even with governmental policies of equal opportunity for women in education and jobs (Anker, 1998; Beck et al, 2003; Peredo, 2001).

Dr. Sunil Deshpande \& Ms. Sunita Sethi (2009) observed that the biggest challenges of women entrepreneurs are dominated by male dominated society, lesser risk and lack of self-confidence.

Rincy.Y.Mathew \& N.Panchantham (2011), their study reveals that obstacles on the entrepreneurial performance of women are lack of role model, lack of professional interaction and lack of adequate training.

\section{REVIEW IN NORTH EASTERN REGION PERSPECTIVE}

In 1994, the name Lalita Devi Jain, fondly known as Madhu by the people of Guwahati, Assam has shaped her own destiny in the entrepreneurial arena. She created her own brand "Madhushree" and has marched her way forward to carve a niche in the global market. She started with five looms and over the period of last more than 25 years, she has built up 50 looms. Almost 200 women are employed and they all have become the part of the family to create the brand of Madhushree. The brand Madhushree shows that dedication and positive attitude can help to develop entrepreneurship among women.

\section{RESEARCH METHOD:}

Descriptive survey method was used to know the existing condition of women entrepreneurship in Sonitpur. The population of the study consists of all the women entrepreneurs in Sonitpur. Sample of study was selected on the basis simple random sampling. Present study was conducted on the basis of both secondary and primary data. Secondary information was collected from District Industrial Centre (DIC) of Sonitpur district and journals, magazines, newspaper and web. The methods used for collecting primary data were observation, telephonic communication, and interview. The primary data were collected from sample of 20 women entrepreneurs through a structured questionnaire

\section{SIGNIFICANCE OF THE STUDY}

An entrepreneur is an important constituent of the development process and an integral part of the socioeconomic transformation process. Full participation of all section of population including women is important for development of a society. Entrepreneurship development among women can be considered a possible approach to economic empowerment of women. Generally when people are empowered to create and manage their own business, it is possible to create wealth, jobs, individual and collective well-being becomes reality. It becomes easier for the Government to redistribute wealth and income when all those who can work are empowered to do so. To be success in entrepreneurial activities, a person have entrepreneurial knowledge and skills and management competencies which have to be acquired (hard skills).

The review of the literature discussed above that there were many studies conducted on entrepreneurship, In Sonitpur district till nowno study is conducted on women entrepreneurship. There is a need for many more micro studies because of variations in geographic, social, cultural, political and economic conditions from state to state and from region to region within the State. Moreover, it is important to throw light on impact of socioeconomic factors on the growth of entrepreneurship in Sonitpur district of Assam. Women entrepreneurs have gradually played an important role in spurring economic development and job creation. Equality among men and women which is essential for development of a society, can possible through economic independence of women. Though government has taken various measures to develop entrepreneurship among women, still it is not encouraging. Therefore it is necessary to know the obstacles of women entrepreneurship and measures be initiated to remove various shortcomings so that participation and contribution of women entrepreneurs to national economy be increased. The present investigator will definitely explore the hidden prospects and challenges of women entrepreneurship and also forward some suggestions in improvement of women entrepreneurship. This study attempts to sketch the role of women entrepreneurs in transforming the standard of life of women. The study has received importance because such an elaborate works has not been undertaken till now. 


\section{Findings and analysis}

Since 60.73 percent women are literate in Sonitpur district, so there is a possibility of exploration of quality of women.

6.1 As per the first objective the necessity of women entrepreneurship in Tezpur

a) Financial independence is regarded by $33 \%$ of total respondents as highest necessity of entrepreneurship for women.

b) $23 \%$ of total respondents are in view of higher standard of living as a necessity of entrepreneurship for women.

c) Economic growth is regarded by $18 \%$ of the total respondents as one of important necessity of entrepreneurship for women.

d) $13 \%$ of the total respondents are in view that identity, social security and awareness of equal rights from male dominant society are regarded as a necessity of

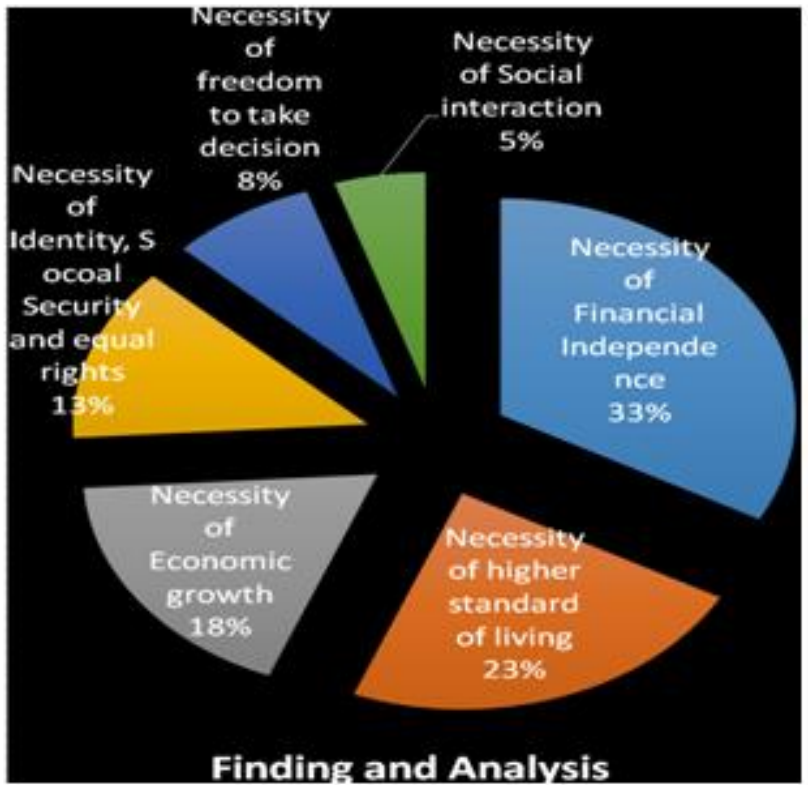

women entrepreneurship for women.

e), Freedom to take decision is another necessity of entrepreneurship for women according to $8 \%$ of total respondents.

f) Social interaction is also another necessity of women entrepreneurship regarded by $5 \%$ of total respondents.

\subsection{Challenges of women entrepreneurship in Sonitpur}

The potential for developing women entrepreneurship in Sonitpur is high. The literacy rate of women in Sonitpur is 60.73 (2011) percent. With the increase of population and urbanisation, the market condition of small enterprises is gradually moving upwards. Moreover, the number of women entrepreneurs increase considerably during recent years due to increase of Self Help Groups (SHGs) under the Swarna Jayanti Gram Swarozgar Yojana(1999). Culturally this district is full of diversity. Due to existence of multicultural ethnic groups, there is a possibility of women entrepreneurship in different fields such as handloom, handicraft, food items, small tea gardens, internet café, restaurants, etc. Moreover, Sonitpur is an important tourist destination place, therefore the possibility of expansion of lodge, restaurant or café is very high. Women entrepreneurs are engaged mainly in activities like weaving, knitting, embroidery, jam jelly and pickle making, etc. In recent years it is seen that women entrepreneurs of Sonitpur are venturing into non-traditional field also. These are mainly establishment of beautipourlar, restaurant, garment shop, agarbatti and candle manufacturing enterprise, internet café, etc. This is partly because of expansion of entrepreneurial opportunities. In Tezpur, Tezpur Mahila Samitee and DIC, Sonitpur have played a significant role in giving training facilities (weaving, knitting, embroidery, etc.) to both urban and rural women. As a result, number of women enterprises have been increased considerably. But this picture is not encouraging. The main challenges of women entrepreneurs in Sonitpur district are:

a) To run any enterprise successfully adequate infrastructure is must. During the present investigation the researcher find out the infrastructural problems like inadequate power supply, inadequate building and space, and also inadequate communication facilities. 36 percent of total respondents are of the view that inadequate infrastructural facility is one of the most important challenges of women entrepreneurs 
b) 32 percent of total respondents considered finance is another main problem. Without financial support it is not possible to start a business. Due to paucity of fund many women are not able to start their business in spite of their willingness. Most of the women entrepreneurs start their own venture but they miss the way of success. Women entrepreneurs hesitate to take financial help from banks because of lengthy and complex process.

c) Women entrepreneurs in our society facing various socio-personal problems which prevented them from becoming potential entrepreneurs. These problems are related to family problems, child rearing, limited freedom and also male dominance. During field work, it was observed that most of the women entrepreneurs have identified the dual responsibilities and conflict arises due to dual responsibilities. There is a lack of recognition and appreciation. 7 percent women are not getting support from their husband and 12 percent women are not get support from their family. Majority of entrepreneurs
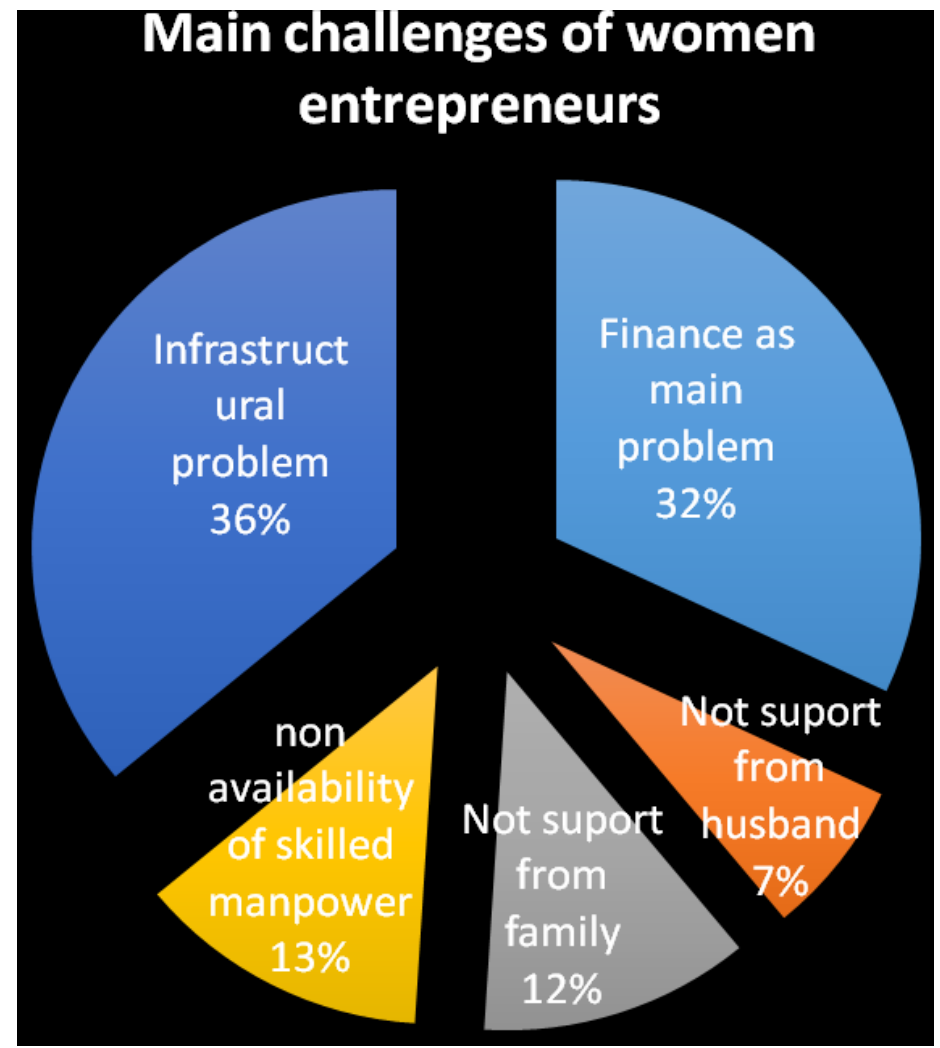
considered entrepreneurship as secondary to their home and family. They have to give importance to their husband, child and their relationship with them. d) Another problem of women entrepreneurs in Sonitpur is non availability of skilled manpower. Most of the entrepreneurs (13 percent) are not getting the opportunities of entrepreneurship training. During the field work it was seen that many women entrepreneurs have lack of knowledge about various government schemes related with training programmes, financial assistance, etc. They have lack of skill and financial support to start new enterprise.

e) Adequate marketing is one of the most important factors of success of any enterprise. Generally marketing depends on quality of products, advertisement or publicity, adequate mobility, knowledge of market etc. But most of the women entrepreneurs have faced the problems of how to market the product, inadequate publicity, difficulty in travelling, competition with big enterprises, high production cost and high tax rate. Lack of knowledge in business related activities are major problems of women entrepreneurship.

\subsection{As per the third objective the ways of overcoming the barriers of women entrepreneurship are:}

In view of the problems cited above, it is realised to adopt appropriate measures to accelerate the development of women entrepreneurship. Following recommendations have been made for the development of women entrepreneurship in Sonitpur

1) The financial institutions mainly commercial banks can play an important role by giving financial help through simple way and also at low rate of interest to women entrepreneurs to encourage them.

2) Awareness among women as well as other people of the society is very much important for women entrepreneurship. In this case, schools and colleges and different NGOs must take initiatives to generate awareness among the girl students. Knowledge of entrepreneurship must be included in curriculum of formal education.

3) Government must give emphasis on expansion of training facilities for women entrepreneurs. Training programmes for women entrepreneurs must be conducted from time to time which should give emphasis on finance generation, management procedure, innovative production and marketing.

4) For unregistered women entrepreneurs, situation must be created so that they are encouraged to register their enterprises to get government facilities and financial assistance from banks.

5) Moral support from family members is very much important for the development of women entrepreneurs.

6) Net working women entrepreneurs. 


\section{CONCLUSION}

Women entrepreneurs have gradually played an important role in spurring economic development and job creation. Equality among men and women which is essential for development of society can possible through economic independence of women. The women entrepreneurs should take the challenges of new economic policy. At the time of independence, entrepreneurship development in Assam was negligible. The potential for development of women entrepreneur in Assam is very high. In Assam, handloom sector is almost handled by women entrepreneurs. Though government has taken various measures to develop women entrepreneurship, still development of women entrepreneurship is not encouraging. Developing entrepreneurship among women will definitely be the right approach for empowerment of women. At present it is a matter of satisfaction that number of women entrepreneurs are coming to start their business in traditional activities like weaving, embroidery, pickle making, knitting, jam jelly making, etc. but also in non-traditional activities like beauty parlour, computer café, crèches, restaurant, readymade garments, nursery, food catering centres,tailoring firms, etc. In this case all kinds of support from family members, government, banks and society are needed. Moreover, expansion of education, financial assistance, training for entrepreneurship, infrastructural development, marketing facilities, family and society support, etc. are also very much important for revolution to entrepreneurship among women.

\section{REFERENCES}

[1] Bhatia, B.S. \& Batra, G.S. (2000), Entrepreneurship and small business management, Deep \& Deep Publications Pvt. Ltd., New Delhi.

[2] Chowdhary R.K., (2001), "Economic Problems of Assam" Kitapghar

[3] Desai, Vasant (1991), Entrepreneurial development, Volume 1, Himalaya Publishing House, Bombay.

[4] Desai, Basant (1997), Dynamics of Entrepreneurial Development and Management, Himalaya Publishing House, New Delhi.

[5] Dhameja S.K. (2008), "Women Entrepreneurs - opportunities, performance, problems". Deep \& Deep Publication Pvt. Ltd. New Delhi.

[6] Dhar Dr. P.K., (2005), "The economy of Assam “, Kalyani Publishing House, New Delhi.

[7] Directorate of Economic \& Statistic, Government of Assam, Statistical Hand Book of Assam, 2010.

[8] Ganasan, S. (2003), 'Status of Women Entrepreneurs in India", Kanishka Publishers and Distributors, New Delhi.

[9] Gupta, B.L. \& Kumar, Anil (2006), Entrepreneurship Development, Quality Publishing House Bhopal.

[10] Gupta, C.B. and Khanka, S.S. (1996), "Entrepreneurship and Small Business Management", Sultan Chand \& Sons, Delhi,

[11] Gupta, C.B. \& Srinivasan N.P. (1997), Entrepreneurship Development in India, S. Chand SonsNew Delhi.

[12] Khanka, S.S. (1990), 'Entrepreneurship in Small-Scale Industries, Indian Entrepreneurship", Himalaya Publishing House, New Delhi.

[13] Khanka S.S. (2009): Entrepreneurship in India - Perspectives and Practices, Akansha Publishing House, New Delhi.

[14] Lalitha, Rani D (1996), “Women Entrepreneurship", APM Publishing Corporation, New Delhi.

[15] Mail, DD (1995), "training for entrepreneurship \& self-employment" Mittal Publication, New Delhi.

[16] NEDFI: Women Enterprise Development.

[17] Nirmala Josephine \& Sathugiri V 2010: Socio Economic Constraints of Women Entrepreneurs, Rural Women Entrepreneurship (edited by Maria Jhon \& others).

[18] Parikh, Indira \& Engineer Mahnik (1999), Women in Management - A movement from 50's to next millennium, Working Paper NO. 99, IIM, Ahmedabad.

[19] Parikh, Indira j \& Garg, Pulin. (1989), Indian Women: An Inner Dialogue, Sage Pub., New Delhi.

[20] Ramya, N. (2006), 'Problems of Women Entrepreneurs', Third Concept, August.

[21] Sinha, Poonam (2000), 'Women Entrepreneurship Development in North East', IIE, Guwahati.

[22] Tapan, N. (2002), 'Need for Women Empowerment", Rawat Publications, Jaipur.

[23] Thakur, Anil Kumar \& Rahman, R. (2009) 'Women Entrepreneurship' Deep \& Deep Publications Pvt. Ltd., New Delhi 